\title{
Dichloromaleimide (diCMI): A Small and Fluorogenic Reactive Group for Use in Affinity Labeling
}

\author{
Kosuke Chiba, Yuichi Hashimoto, and Takao Yamaguchi* \\ Institute of Molecular and Cellular Biosciences, The University of Tokyo; 1-1-1 Yayoi, Bunkyo-ku, Tokyo 113-0032, \\ Japan. \\ Received June 21, 2016; accepted August 17, 2016
}

\begin{abstract}
Chemical probes comprising a ligand moiety, a reactive group (e.g. epoxide, haloacetyl or photoreactive group) and a tag unit (e.g. fluorophore or radioisotope) are widely used in affinity labeling to identify the target proteins of bioactive molecules. However, design and synthesis of highly functionalized chemical probes are often time-consuming. In this paper, we propose a simple design strategy for chemical probes bearing a small 2,3-dichloromaleimide (diCMI) unit, which serves as a combined reactive group and tag unit by reacting with a nucleophilic lysine residue near the ligand-binding site of the target protein to generate the 2-amino-3-chloromaleimide fluorophore. Model ligand-protein experiments confirmed that the diCMI unit has suitable reactivity and fluorogenic capability for efficient affinity labeling.
\end{abstract}

Key words affinity labeling; dichloromaleimide; protein modification

Affinity labeling is a powerful method to label and visualize target proteins of bioactive molecules. ${ }^{1,2)}$ This method generally utilizes a chemical probe composed of a ligand moiety, a reactive group and a tag unit (Fig. 1a). The reactive group serves to form a covalent bond with the target protein. For efficient and specific target labeling, the reactive group should be stable in aqueous media, have low reactivity towards non-target molecules, and react appropriately with the target protein after ligand-target binding. The tag unit serves to visualize the target protein. Fluorophores are often used as a tag unit because of the ease of detection. However, a major obstacle to affinity labeling is often synthesis of the highly functionalized chemical probe. More importantly, the ligand must retain its binding affinity after introduction of these two functional groups (reactive group and tag unit). For these reasons, a small alkyne tag is often used in affinity labeling, since it can be subsequently conjugated with a detection unit (e.g. azide-fluorophore, azide-biotin), despite the inconvenience of the additional conjugation step(s). ${ }^{3)}$ We recently reported a small alkoxy nitrobenzoxadiazole $(O-\mathrm{NBD}, 180 \mathrm{Da})$ unit as a fluorogenic reactive group for affinity labeling. ${ }^{4}$ Here, we show that 2,3-dichloromaleimide (diCMI, 164 Da) can serve as an even smaller fluorogenic reactive group (Fig. 1b).

\section{Results and Discussion}

Molecular Design, Model Reaction and Spectrometric Analysis The maleimide motif is a highly reactive Michael acceptor and has been widely used for chemical modification of thiols of biomolecules. ${ }^{5-7)}$ For instance, fluorophore-conjugated maleimides have been employed for the modification of cysteine residues. ${ }^{89}$ Recently, 2-bromomaleimide and 2,3-dibromomaleimide were developed as novel cysteine-labeling reagents, which react with thiol in an addition-elimination sequence (nucleophilic substitution) to afford thiomaleimide. ${ }^{10-18)}$ In an organic solvent such as tetrahydrofuran (THF), 2,3-dibromomaleimide also reacts with amine, affording 2-amino-3-bromomaleimide as an amine-conjugation product. Interestingly, 2-aminomaleimides were recently reported to exhibit strong fluorescence at $>400 \mathrm{~nm}$ with large Stokes shifts $(>100 \mathrm{~nm}) .{ }^{19)}$ We thus initially expected that 2,3-dibromomaleimide would be available as a fluorogenic reactive group for lysine residues. However, to our knowledge, reaction of 2,3-dibromomaleimide and amine in aqueous media (or alcohols) has not been reported. On the other hand, 2,3-dichloromaleimides react with amine in alcohols. ${ }^{20)}$ Therefore, we selected diCMI as a candidate fluorogenic reactive group for use in affinity labeling.

To evaluate the reactivity of the diCMI unit, we first examined the reaction of $N$ - $n$-butyl-2,3-dichloromaleimide (1) with $n$-propylamine in $\mathrm{H}_{2} \mathrm{O}-\mathrm{THF}(1: 2)$ (Table 1 , entry 1$)$. Nearly $50 \%$ of the starting material was converted to the desired product $\mathbf{2 a}$ within $1 \mathrm{~h}$, and $\mathbf{3 a}$ was obtained in $17 \%$ yield. Importantly, this result revealed that the diCMI unit is stable in aqueous media and exhibits moderate reactivity with amine. It is noteworthy that this reaction was carried out at high concentration $(0.10 \mathrm{M})$, which mimics a reaction promoted by ligand-target interaction. To our surprise, dichloromaleimide 1 showed no reactivity with 1-propanethiol even in the presence of excess thiol (entries 2, 3). We further tested these reactions in phosphate buffer $(\mathrm{pH}$ 7.0)/THF considering the possible $\mathrm{pH}$ effect (entries 4,5 ). As a result, amine adduct 2a and thiol adduct $\mathbf{2 b}$ were obtained in 12 and $73 \%$, respectively. This means that dichloromaleimide reacts with both amine and thiol under neutralized aqueous conditions.

Next, UV-Vis and fluorescence properties of $\mathbf{1}, \mathbf{2 a}$ and $\mathbf{b}$ were evaluated (Figs. 2a, b). As shown in Fig. 2a, the amine adduct 2a was found to show a maximum absorbance at $c a$. $375 \mathrm{~nm}$ similar to a reported 2-aminomaleimide fluorophore, 2-bromo-3- $n$-butylamino- $N$-methylmaleimide (4). ${ }^{19)}$ As expected, 2a exhibited strong fluorescence (Fig. $2 \mathrm{~b}, \lambda_{\mathrm{ex}}: 374 \mathrm{~nm}, \lambda_{\mathrm{em}}$ : $482 \mathrm{~nm}$ in 1,4-dioxane), whereas 1 showed no significant fluorescence (data not shown). Moreover, the thiol adduct $\mathbf{2 b}$ was found to show weak fluorescence $\left(\lambda_{\mathrm{ex}}: 372 \mathrm{~nm}, \lambda_{\mathrm{em}}: 471 \mathrm{~nm}\right)$. These fluorescence data, as well as the above reactivity data, indicate that the diCMI unit would be suitable for fluorogenic labeling of amines and thiols, with much higher fluorescence 


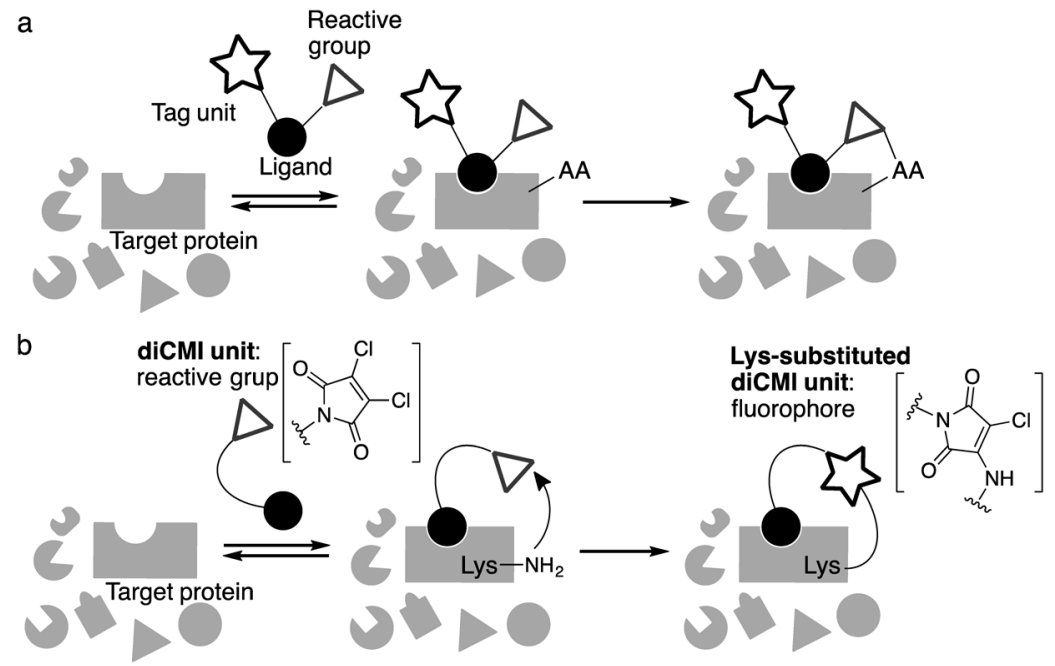

Fig. 1. Schematic Representation of Affinity Labeling

(a) General affinity labeling using a reactive group and a tag unit. AA means an amino acid residue near the ligand-binding site. (b) Simple affinity labeling method using the small diCMI unit. The diCMI unit reacts with a nucleophilic lysine (Lys) residue near the ligand-binding site to afford the 2-amino-3-chloromaleimide fluorophore.

Table 1. Reaction of $\mathbf{1}$ with $n$-Propylamine/1-Propanethiol

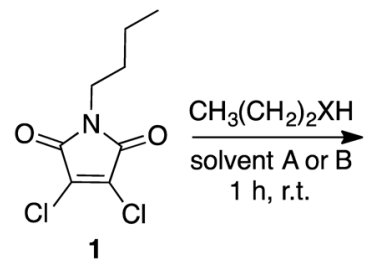<smiles>[R4]N=NC1=C(Cl)C(=O)N(CCCC)C1=O</smiles>

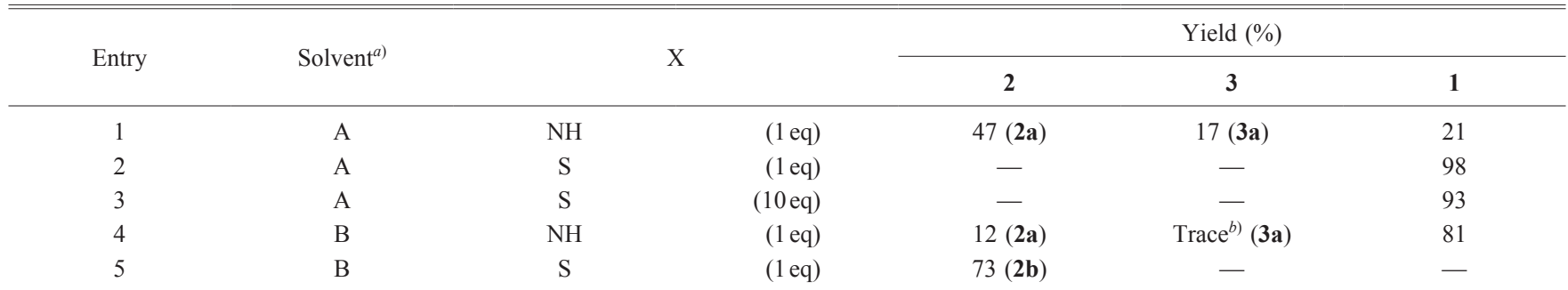

a) Solvent A: $\mathrm{H}_{2} \mathrm{O}-\mathrm{THF}(1: 2)$, solvent B: phosphate buffer $(0.6 \mathrm{M}, \mathrm{pH} 7.0)$-THF $\left.(1: 2) . b\right)$ This compound was observed in the ${ }^{1} \mathrm{H}-\mathrm{NMR}$ spectrum of crude material. Reaction conditions: $1(0.10 \mathrm{M}$ (entries $1-3), 20 \mathrm{~mm}$ (entries 4,5$)), n$-propylamine/1-propanethiol $(0.10$ or $1.0 \mathrm{M}($ entries $1-3), 20 \mathrm{~mm}($ entries 4,5$))$, r.t., and $1 \mathrm{~h}$.
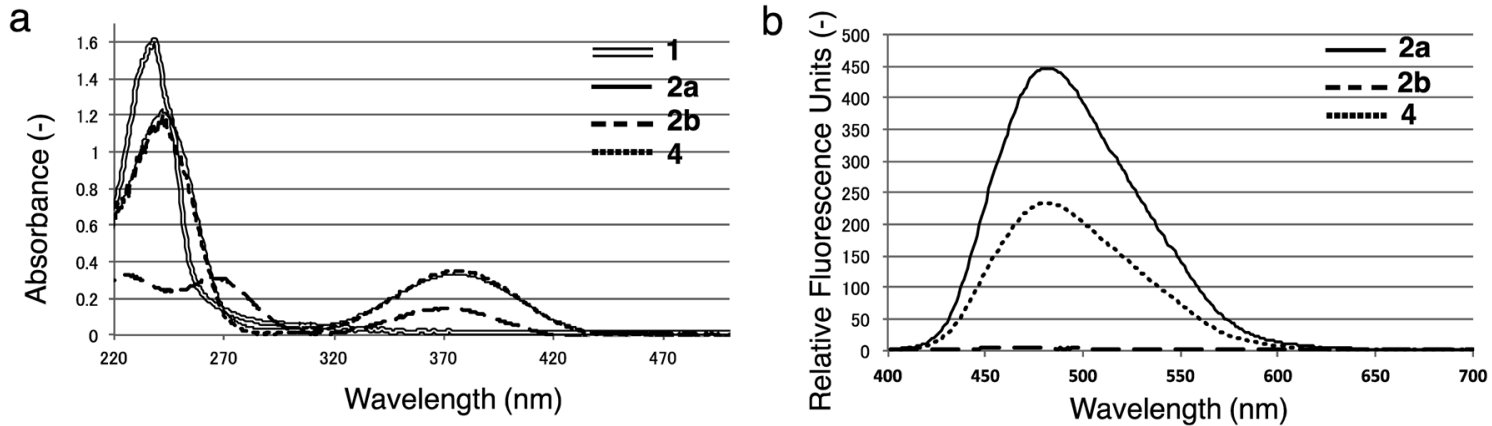

Fig. 2. Spectral Analysis of 1, 2a and $\mathbf{b}$

2-Bromo-3- $n$-butylamino- $N$-methylmaleimide (4) was used as a standard. ${ }^{19)}$ (a) UV-Vis spectra of 1, 2a, b and 4. Measurement conditions: $100 \mu \mathrm{M}$ compound in 1,4-dioxane. The molar extinction coefficients were calculated from the maximum absorption $\left(\varepsilon_{\mathrm{max}}: 3400 \mathrm{M}^{-1} \mathrm{~cm}^{-1}\right.$ at $375 \mathrm{~nm}$ for $\mathbf{2 a}, 1501 \mathrm{M}^{-1} \mathrm{~cm}^{-1}$ at $372 \mathrm{~nm}$ for $\mathbf{2} \mathbf{b}$ and $3500 \mathrm{~m}^{-1} \mathrm{~cm}^{-1}$ at $376 \mathrm{~nm}$ for 4). ${ }^{19)}$ (b) Fluorescence spectra of $\mathbf{2 a}, \mathbf{b}$ and $\mathbf{4}$. Measurement conditions: $100 \mu \mathrm{M}$ compound in 1,4-dioxane. The standard compound $\mathbf{4}$ was excited at $374 \mathrm{~nm}$ as reported. The relative fluorescence quantum yields $\left(\phi_{\mathrm{f}}\right)$ of $\mathbf{2 a}$ and $\mathbf{b}$ were found to be $0.40\left(\lambda_{\mathrm{ex}}: 375 \mathrm{~nm}\right)$ and $0.018\left(\lambda_{\mathrm{ex}}: 372 \mathrm{~nm}\right)$, respectively. 

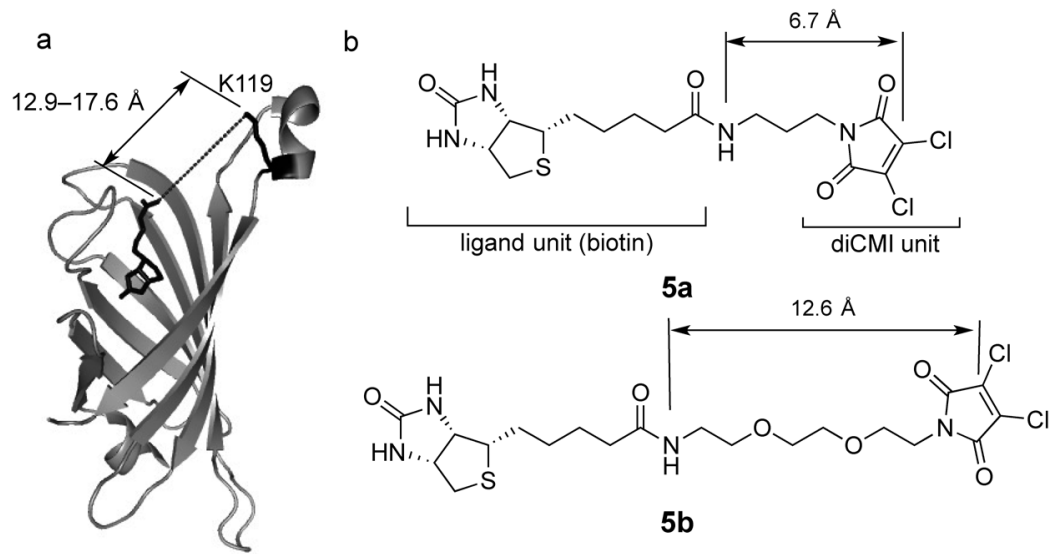

Fig. 3. The Designed Biotin-diCMI Probe Molecules for Labeling of Streptavidin

(a) Structure model of biotin-streptavidin complex (PDB ID: 1STP, monomer state is shown ${ }^{22}$ ). The biotin molecule and lysine 119 (K119) are shown in black. The distance between the biotin carbonyl group and streptavidin K119 was estimated by PyMOL software. (b) Structures of the designed biotin-diCMI probe molecules. The linker lengths were calculated using ChemBio 3D Ultra 13.0 software with MM2 energy minimization.<smiles>O=C(O)CCCCC1SCC2NC(=O)NC21</smiles>

(+)-biotin<smiles>[Y]C(N)=NCCNC(=O)CCCCC1SCC2NC(=O)NC21</smiles>

6a,b

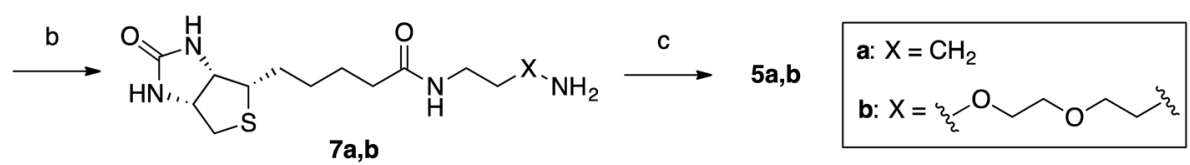

Reagents and conditions: (a) $N$-Hydroxysuccinimide, EDCI, DIPEA, $N$-Boc-1,3-diaminopropane or $N$-Boc-1,8-diamino-3,6-dioxaoctane, DMF, r.t., 46\% for 6a, 36\% for 6b; (b) TFA, DCM, $0^{\circ} \mathrm{C}$ to r.t., quant.; (c) 2,3-Dichloromaleic anhydride, AcOH, reflux, $24 \%$ for $\mathbf{5 a}, 57 \%$ for $\mathbf{5 b}$.

Chart 1. Synthesis of the Designed Probe Molecules

intensity of the amine adduct. The relative fluorescence quantum yields $\left(\phi_{\mathrm{f}}\right)$ of $\mathbf{2 a}$ and $\mathbf{b}$ were found to be 0.40 and 0.018 , respectively, by comparison with $\left.4\left(\phi_{\mathrm{f}}=0.20\right) .{ }^{19}\right)$ 2-Amino3 -chloromaleimide fluorophores are likely to have better fluorescence properties than 2-amino-3-bromomaleimides because of the intramolecular heavy atom effect ( $\mathrm{Cl}$ versus $\mathrm{Br})$, as seen in 7-(diethylamino)coumarin derivatives. ${ }^{21)} \mathrm{We}$ also note that 2a shows a solvatochromic character (data not shown), like 2-aminomaleimide. ${ }^{19)}$

Probe Design and Synthesis To confirm the usefulness of the diCMI unit for affinity labeling, we selected biotin-streptavidin as a model ligand-target protein because of their ready availability. Biotin-diCMI probes were designed based on the reported X-ray crystal structure of biotin-streptavidin complex (PDB ID: 1STP, a monomer state is shown ${ }^{22)}$ ) (Fig. 3). It is well known that the carboxylic acid end of biotin has a low impact on the binding affinity. Therefore, the diCMI unit was attached to biotin at this position via a linker unit (Fig. 3b). The distances between the diCMI unit and the amides of $\mathbf{5 a}$ and $\mathbf{b}$ were calculated to be 6.7 and $12.6 \AA$, respectively. Since lysine 119 (K119), the nearest lysine residue to the ligandbinding site, is located $12.9-17.6 \AA$ from the carboxylic acid end of biotin, $\mathbf{5 b}$ was expected to react more efficiently than 5a with streptavidin. We note that streptavidin has no cysteine residues; thus this labeling takes place without involving thiol species. Importantly, the synthesis of the designed biotindiCMI probes was achieved in only three steps from biotin; conjugation of a linker unit, followed by deprotection of the tert-butoxycarbonyl (Boc) group, and reaction with dichloromaleic anhydride to afford the probes 5a and $\mathbf{b}$ (Chart 1).

Evaluation of Streptavidin Labeling We next evaluated fluorescence labeling of streptavidin, the model target protein, by using 2,3-dichloromaleimides 1, 5a and b (Fig. 4). The labeling reaction was performed in phosphate buffer $(\mathrm{pH}$ 7.0) at $0^{\circ} \mathrm{C}$. After the reaction, sodium dodecyl sulfate (SDS) sample buffer was added and each sample was subjected to polyacrylamide gel electrophoresis (PAGE). Labeled streptavidin was visualized using an in-gel fluorescence imager and then stained with Coomassie Brilliant Blue (CBB). As shown in Fig. 4a, both $\mathbf{5 a}$ and $\mathbf{b}$ were found to label the target streptavidin (lanes 3,4 ). The probe $\mathbf{5 b}$ showed stronger fluorescence than $\mathbf{5 a}$, which probably means that the diCMI unit of $\mathbf{5 b}$ had better access to K119. In the case of compound $\mathbf{1}$ (diCMI without the ligand unit), almost no labeling took place under the same conditions (lane 2). Furthermore, the labeling of streptavidin by $\mathbf{5 b}$ was inhibited by addition of biotin as a competitor (Fig. 4b). These results indicate that the labeling reaction was accelerated by the biotin-streptavidin interaction. We then examined the target selectivity of diCMI probe molecules in the presence of non-target proteins, bovine serum albumin (BSA) and carbonic anhydrase II (CAII). Under these conditions, both $\mathbf{5 a}$ and $\mathbf{b}$ labeled the target streptavidin (Fig. 4c, lanes 1,3), but sufficient target-selectivity was observed with the designed $\mathbf{5 b}$. Although non-target BSA was also labeled in some degree, competition analysis importantly revealed that the target streptavidin was specifically labeled by 

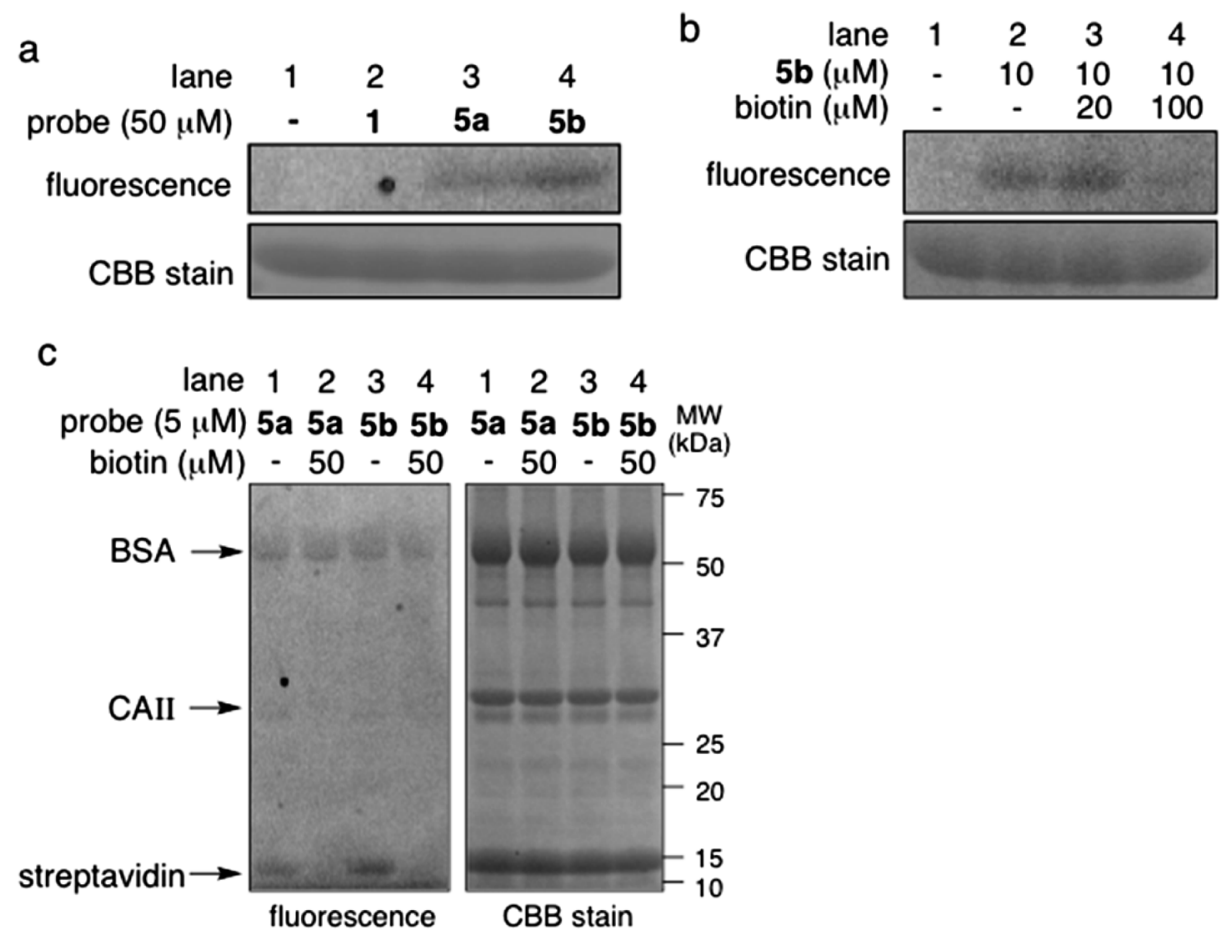

Fig. 4. In-Gel Fluorescence Analysis of Streptavidin Labeled with Biotin-diCMI Probe Molecules $\left(\lambda_{\mathrm{ex}}: 440-500 \mathrm{~nm}, \lambda_{\mathrm{em}}>540 \mathrm{~nm}\right)$

(a) Labeling of streptavidin with $\mathbf{1}, \mathbf{5} \mathbf{a}$, or $\mathbf{b}$. Labeling efficiencies were determined from the fluorescence intensities. Labeling conditions: $50 \mu \mathrm{M}$ streptavidin, $50 \mu \mathrm{M}$ probe, $20 \mathrm{~mm}$ phosphate buffer, $\mathrm{pH} 7.0,0^{\circ} \mathrm{C}$, and $30 \mathrm{~min}$. (b) Competition analysis with biotin. Labeling conditions: $10 \mu \mathrm{m}$ streptavidin, $10 \mu \mathrm{m} \mathbf{5 b}, 20 \mathrm{~mm}$ phosphate buffer, $\mathrm{pH} 7.0,0^{\circ} \mathrm{C}$, and $30 \mathrm{~min}$. Streptavidin was pre-incubated with 20 or $100 \mu \mathrm{m}$ biotin for $30 \mathrm{~min}$ at $0^{\circ} \mathrm{C}$ before addition of $\mathbf{5 b}$. (c) Selective labeling of the target protein (streptavidin) in a mixture of streptavidin, BSA and carbonic anhydrase II (CAII). Labeling conditions: $5 \mu \mathrm{m}$ streptavidin, $1 \mu \mathrm{m}$ BSA, $1 \mu \mathrm{M}$ CAII, $5 \mu \mathrm{M} \mathbf{5 a}$ or $\mathbf{b}$, $20 \mathrm{~mm}$ phosphate buffer, $\mathrm{pH} 7.0,0^{\circ} \mathrm{C}$, and $30 \mathrm{~min}$. For competition analysis (lanes 2,4 ), protein mixture was pre-incubated with $50 \mu \mathrm{m}$ biotin for $30 \mathrm{~min}$ at $0^{\circ} \mathrm{C}$ before an addition of $\mathbf{5 a}$ or $\mathbf{b}$.

5a or b through ligand-target interactions (lanes 2, 4). This result demonstrated that the diCMI unit has suitable reactivity for target-specific labeling.

\section{Conclusion}

We have examined the utility of the diCMI unit as a fluorogenic reactive group for affinity labeling. diCMI was stable in aqueous media and showed sufficient reactivity with amine. Spectrometric analysis revealed that 2-amino-3-chloromaleimide has strong fluorescence. Model experiments with the biotin-streptavidin system confirmed that the diCMI unit has excellent characteristics for target-specific labeling. Notably, diCMI-based chemical probes are simple to design and synthesize. Since the diCMI unit is small, the biological activity of the ligand is likely to be well retained. Thus, the diCMI unit is expected to be useful for affinity labeling.

\section{Experimental \\ Chemistry}

Synthetic Procedures

Chemicals were purchased from Sigma-Aldrich Co. LLC (U.S.A.), Kanto Chemical Co., Inc. (Japan), Tokyo Chemical Industry Co., Ltd. (Japan), Acros Organics (U.S.A.) or Wako Pure Chemical Industries, Ltd. (Japan), and used without further purification. Reactions were monitored by TLC (Merck silica gel $60 \mathrm{~F}_{254}$ ) plate. Bands were visualized using UV light or appropriate reagents followed by heating. Flash chromatography was carried out with silica gel (Silica gel $60 \mathrm{~N}$, 40-50 $\mu \mathrm{m}$ particle size) purchased from Kanto Chemical Co., Inc. NMR spectra were recorded on a JEOL JNM-GX500 or JNMECA-500 spectrometer, operating at $500 \mathrm{MHz}$ for
${ }^{1} \mathrm{H}-\mathrm{NMR}$ and at $125 \mathrm{MHz}$ for ${ }^{13} \mathrm{C}-\mathrm{NMR}$. High-resolution mass spectra (HR-MS) were obtained using a BRUKER micrOTOF II mass spectrometer.

$N$-n-Butyl-2,3-dichloromaleimide (1)

$n$-Butylamine $(148 \mu \mathrm{L}, 1.50 \mathrm{mmol})$ was added to a solution of dichloromaleic anhydride $(250 \mathrm{mg}, 1.50 \mathrm{mmol})$ in acetic acid $(1.00 \mathrm{~mL})$ and the mixture was stirred at room temperature for $30 \mathrm{~min}$, and then refluxed for $4 \mathrm{~h}$. After cooling to room temperature, the mixture was added saturated aq. $\mathrm{NaHCO}_{3}$. The whole was extracted with AcOEt. The combined organic layer was dried over $\mathrm{Na}_{2} \mathrm{SO}_{4}$ and concentrated. The residue was purified by flash silica-gel chromatography (AcOEt- $n$ hexane $=1: 20)$ to afford $1(313 \mathrm{mg}, 1.41 \mathrm{mmol}, 94 \%)$ as a colorless oil. 1: ${ }^{1} \mathrm{H}-\mathrm{NMR}\left(\mathrm{CDCl}_{3}\right) \delta$ : $0.86(3 \mathrm{H}, \mathrm{t}, J=7.4 \mathrm{~Hz}), 1.25$ $(2 \mathrm{H}, \mathrm{tq}, J=7.4,7.4 \mathrm{~Hz}), 1.53(2 \mathrm{H}, \mathrm{tt}, J=7.5,7.5 \mathrm{~Hz}), 3.53(2 \mathrm{H}$, $\mathrm{t}, J=7.2 \mathrm{~Hz}) .{ }^{13} \mathrm{C}-\mathrm{NMR}\left(\mathrm{CDCl}_{3}\right) \delta: 13.6,20.0,30.6,39.3,133.3$, 163.2. HR-MS (electrospray ionization (ESI)) $\mathrm{m} / \mathrm{z}: 276.0170$ (Calcd for $\mathrm{C}_{8} \mathrm{H}_{9} \mathrm{Cl}_{2} \mathrm{NO}_{2}\left(\mathrm{M}+\mathrm{MeOH}+\mathrm{Na}^{+}\right)$: 276.0170).

$\mathrm{N}$-n-Butyl-2-chloro-3-(n-propylamino)maleimide (2a)

$N^{1}$-n-Butyl-2,3-dichloro- $N^{4}$-propylmaleamide (3a)

$n$-Propylamine $(8.20 \mu \mathrm{L}, 0.100 \mathrm{mmol})$ was added to a solution of 1 ( $22.2 \mathrm{mg}, 0.100 \mathrm{mmol})$ in $\mathrm{H}_{2} \mathrm{O}-\mathrm{THF}(0.900 \mathrm{~mL}, 1: 2)$ at room temperature, and the mixture was stirred for $1 \mathrm{~h}$. After the reaction, the mixture was immediately concentrated under reduced pressure. The residue was purified by flash silca-gel chromatography (AcOEt- $n$-hexane $=1: 15$ to $1: 2)$ to afford 2a $(11.5 \mathrm{mg}, 47.0 \mu \mathrm{mol}, 47 \%)$ as a yellow solid and $\mathbf{3 a}(4.80 \mathrm{mg}$, $17.1 \mu \mathrm{mol}, 17 \%)$ as a white solid. 2a: ${ }^{1} \mathrm{H}-\mathrm{NMR}\left(\mathrm{CDCl}_{3}\right) \delta$ : $0.82(3 \mathrm{H}, \mathrm{t}, J=7.2 \mathrm{~Hz}), 0.92(3 \mathrm{H}, \mathrm{t}, J=7.4 \mathrm{~Hz}), 1.23(2 \mathrm{H}, \mathrm{tq}$, $J=7.5,7.5 \mathrm{~Hz}), 1.48(2 \mathrm{H}, \mathrm{tt}, J=7.5,7.5 \mathrm{~Hz}), 1.61(2 \mathrm{H}, \mathrm{tq}, J=7.2$, $7.2 \mathrm{~Hz}), 3.41(2 \mathrm{H}, \mathrm{t}, J=7.2 \mathrm{~Hz}), 3.49(2 \mathrm{H}, \mathrm{dt}, J=7.2,7.2 \mathrm{~Hz})$, 
$5.32\left(1 \mathrm{H}\right.$, br s). ${ }^{13} \mathrm{C}-\mathrm{NMR}\left(\mathrm{CDCl}_{3}\right) \delta: 11.0,13.7,20.0,24.2$, 30.6, 30.8, 38.2, 44.9, 88.7, 140.4, 165.9, 168.1. HR-MS (ESI) $m / z$ : 267.0871 (Calcd for $\mathrm{C}_{11} \mathrm{H}_{17} \mathrm{ClN}_{2} \mathrm{O}_{2}\left(\mathrm{M}+\mathrm{Na}^{+}\right)$: 267.0871). 3a: ${ }^{1} \mathrm{H}-\mathrm{NMR}\left(\mathrm{CDCl}_{3}\right) \delta$ : $0.86-0.88(6 \mathrm{H}, \mathrm{m}), 1.30$ (tq, $J=6.0$, $6.0 \mathrm{~Hz}), 1.44-1.54$ (4H, m), 3.20-3.27 (4H, m), 6.442 (2H, br s). ${ }^{13} \mathrm{C}-\mathrm{NMR}\left(\mathrm{CDCl}_{3}\right) \delta$ : 11.4, 13.8, 20.1, 22.5, 31.2, 40.2, 42.2, 130.8, 130.9, 161.6, 161.7. HR-MS (ESI) m/z: 303.0651 (Calcd for $\mathrm{C}_{11} \mathrm{H}_{18} \mathrm{Cl}_{2} \mathrm{~N}_{2} \mathrm{O}_{2}\left(\mathrm{M}+\mathrm{Na}^{+}\right)$: 303.0638).

$N$ - $n$-Butyl-2-chloro-3-(n-propylthio)maleimide (2b)

Propanethiol $(9.10 \mu \mathrm{L}, 0.100 \mathrm{mmol})$ was added to a solution of 1 (22.2 $\mathrm{mg}, 0.100 \mathrm{mmol})$ in phosphate buffer $(0.6 \mathrm{M}, \mathrm{pH} 7.0)$ THF $(5.00 \mathrm{~mL}, 1: 2)$ at room temperature, and the mixture was stirred for $1 \mathrm{~h}$. Then the mixture was added $\mathrm{H}_{2} \mathrm{O}$ and the whole was extracted with AcOEt. The combined organic layer was dried over $\mathrm{Na}_{2} \mathrm{SO}_{4}$ and concentrated. The residue was purified by flash silica-gel chromatography (AcOEt- $n$-hexane $=1: 15)$ to afford $\mathbf{2 b}(19.2 \mathrm{mg}, 73.3 \mu \mathrm{mol}, 73 \%)$ as a yellow oil. 2b: ${ }^{1} \mathrm{H}-\mathrm{NMR}\left(\mathrm{CDCl}_{3}\right) \delta$ : $0.92(3 \mathrm{H}, \mathrm{t}, J=7.5 \mathrm{~Hz}), 1.04(3 \mathrm{H}$, t, $J=7.3 \mathrm{~Hz}), 1.30(2 \mathrm{H}, \mathrm{tq}, J=7.5,7.5 \mathrm{~Hz}), 1.56(2 \mathrm{H}, \mathrm{tt}, J=7.4$, $7.5 \mathrm{~Hz}), 1.72(2 \mathrm{H}, \mathrm{tq}, J=7.3,7.3 \mathrm{~Hz}), 3.33(2 \mathrm{H}, \mathrm{t}, J=7.5 \mathrm{~Hz})$, $3.53(2 \mathrm{H}, \mathrm{t}, J=7.3 \mathrm{~Hz}) \cdot{ }^{13} \mathrm{C}-\mathrm{NMR}\left(\mathrm{CDCl}_{3}\right) \delta: 13.1,13.6,20.0$, 24.1, 30.6, 32.5, 38.8, 126.7, 139.0, 164.5, 166.0. HR-MS (ESI) $m / z$ : 284.0480 (Calcd for $\mathrm{C}_{11} \mathrm{H}_{16} \mathrm{ClNO}_{2} \mathrm{~S}\left(\mathrm{M}+\mathrm{Na}^{+}\right)$: 284.0482).

2-Bromo-3- $n$-butylamino- $N$-methylmaleimide (4)

Compound 4 was prepared differently from the reported procedure. ${ }^{19)} n$-Butylamine $(18.4 \mu \mathrm{L}, 0.190 \mathrm{mmol})$ was added to a solution of 2,3-dibromo- $N$-methylmaleimide $(50.0 \mathrm{mg}$, $0.190 \mathrm{mmol})$ in methanol $(2.00 \mathrm{~mL})$ at room temperature, and the mixture was stirred for $5 \mathrm{~h}$. The mixture was then concentrated and the residue was purified by flash silica-gel chromatography (AcOEt $-n$-hexane $=1: 15$ to $1: 10$ ) to afford $4(23.5 \mathrm{mg}, 0.0900 \mathrm{mmol}, 47 \%)$ as a yellow solid. 4: ${ }^{1} \mathrm{H}-\mathrm{NMR}$ $\left(\mathrm{CDCl}_{3}\right) \delta: 0.97(3 \mathrm{H}, \mathrm{t}, J=7.4 \mathrm{~Hz}), 1.42(2 \mathrm{H}, \mathrm{tq}, J=7.5,7.5 \mathrm{~Hz})$, $1.64(2 \mathrm{H}, \mathrm{tt}, J=7.5,7.5 \mathrm{~Hz}), 3.02(3 \mathrm{H}, \mathrm{s}), 3.64(2 \mathrm{H}, \mathrm{dt}, J=7.0$, 7.0 Hz). HR-MS (ESI) $m / z$ : 283.0050 (Calcd for $\mathrm{C}_{9} \mathrm{H}_{13} \mathrm{BrN}_{2} \mathrm{O}_{2}$ $\left.\left(\mathrm{M}+\mathrm{Na}^{+}\right): 283.0053\right)$.

3-Biotinylamino- $N$-(tert-butoxycarbonyl)propylamine (6a)

$\mathrm{N}$-Hydroxysuccinimide $(380 \mathrm{mg}, 3.30 \mathrm{mmol})$ and $1-(3-$ dimethylaminopropyl)-3-ethylcarbodiimide ( $863 \mathrm{mg}, 4.50 \mathrm{mmol})$ were added to a solution of (+)-biotin $(733 \mathrm{mg}, 3.00 \mathrm{mmol})$ in anhydrous $N, N$-dimethylformamide (DMF) $(13.0 \mathrm{~mL})$, and the mixture was stirred for $6 \mathrm{~h}$ at room temperature under an $\mathrm{Ar}$ atmosphere. $N$-Boc-1,3-diaminopropane $(575 \mathrm{mg}, 3.30 \mathrm{mmol})$ in DMF $(2.00 \mathrm{~mL})$ and $N, N$-diisopropylethylamine $(1.55 \mathrm{~mL}$, $9.00 \mathrm{mmol}$ ) were then added, and the resulting mixture was stirred for $21 \mathrm{~h}$ at room temperature. After removal of the solvent, the residue was purified by flash silica-gel chromatography $\left(\mathrm{CHCl}_{3}-\mathrm{MeOH}=20: 1\right)$ to afford $\mathbf{6 a}(550 \mathrm{mg}, 1.37 \mathrm{mmol}$, $46 \%)$ as a white solid. 6a: ${ }^{1} \mathrm{H}-\mathrm{NMR}\left(\mathrm{CDCl}_{3}\right) \delta$ : $1.44-1.46$ $(11 \mathrm{H}, \mathrm{m}), 1.66-1.72(6 \mathrm{H}, \mathrm{m}), 2.22(2 \mathrm{H}, \mathrm{t}, J=7.7 \mathrm{~Hz}), 2.73(1 \mathrm{H}$, d, $J=13.2 \mathrm{~Hz}), 2.91(1 \mathrm{H}, \mathrm{dd}, J=5.2,12.6 \mathrm{~Hz}), 3.13-3.17(3 \mathrm{H}$, m), $3.28(2 \mathrm{H}, \mathrm{tt}, J=6.6,6.6 \mathrm{~Hz}), 4.32(1 \mathrm{H}, \mathrm{dd}, J=4.8,7.8 \mathrm{~Hz})$, $4.52(1 \mathrm{H}, \mathrm{dd}, J=4.8,7.8 \mathrm{~Hz}), 5.08(1 \mathrm{H}, \mathrm{brs}), 5.83(1 \mathrm{H}, \mathrm{brs})$, 6.65 (1H, brs), 6.77 (1H, brs). ${ }^{13} \mathrm{C}-\mathrm{NMR}\left(\mathrm{CDCl}_{3}\right) \delta: 25.9,28.1$, 28.3, 28.5, 30.1, 36.0, 36.2, 37.4, 40.6, 55.8, 60.3, 61.8, 79.4, 156.7, 164.3, 173.8. HR-MS (ESI) $\mathrm{m} / z$ : 423.2051 (Calcd for $\left.\mathrm{C}_{18} \mathrm{H}_{32} \mathrm{~N}_{4} \mathrm{O}_{4} \mathrm{~S}\left(\mathrm{M}+\mathrm{Na}^{+}\right): 423.2036\right)$.

$N$-tert-Butoxycarbonyl-2-(2-(2-(biotinylamino)ethoxy)ethoxy)ethylamine (6b)

Compound $\mathbf{6 b}$ was prepared differently from the reported procedure. ${ }^{23)} \mathrm{N}$-Hydroxysuccinimide $(90.0 \mathrm{mg}, 0.780 \mathrm{mmol})$ and 1-(3-dimethylaminopropyl)-3-ethylcarbodiiimide (205 mg, $1.07 \mathrm{mmol})$ were added to a solution of $(+)$-biotin $(173 \mathrm{mg}$, $0.710 \mathrm{mmol})$ in anhydrous DMF $(3.00 \mathrm{~mL})$, and the mixture was stirred for $2 \mathrm{~h}$ at room temperature under an Ar atmosphere. $N$-Boc-1,8-diamino-3,6-dioxaoctane (166 mg, $0.710 \mathrm{mmol})$ in DMF $(2.00 \mathrm{~mL})$ and $N, N$-diisopropylethylamine $(367 \mu \mathrm{L}, 2.13 \mathrm{mmol})$ were then added, and the resulting mixture was stirred for $24 \mathrm{~h}$ at room temperature. After removal of the solvent, the residue was purified by flash silica-gel chromatography $\left(\mathrm{CHCl}_{3}-\mathrm{MeOH}=10: 1\right)$ to afford $\mathbf{6 b}(121 \mathrm{mg}$, $0.256 \mathrm{mmol}, 36 \%)$ as a white solid. 6b: ${ }^{1} \mathrm{H}-\mathrm{NMR}\left(\mathrm{CDCl}_{3}\right) \delta$ : 1.41-1.43 (11H, m), 1.63-1.76 (4H, m), $2.23(2 \mathrm{H}, \mathrm{t}, J=7.4 \mathrm{~Hz})$, $2.74(1 \mathrm{H}, \mathrm{d}, J=12.6 \mathrm{~Hz}), 2.90(1 \mathrm{H}, \mathrm{dd}, J=4.9,12.9 \mathrm{~Hz})$, 3.13-3.16 (2H, m), 3.30-3.32 (1H, m), $3.42(2 \mathrm{H}, \mathrm{dt}, J=5.0$, $5.0 \mathrm{~Hz}), 3.55(2 \mathrm{H}, \mathrm{t}, J=5.0 \mathrm{~Hz}), 3.57(2 \mathrm{H}, \mathrm{t}, J=5.0 \mathrm{~Hz}), 3.62$ (4H, brs), $4.30(1 \mathrm{H}, \mathrm{dd}, J=4.5,7.5 \mathrm{~Hz}), 4.50(1 \mathrm{H}, \mathrm{dd}, J=5.0$, $7.5 \mathrm{~Hz}), 5.37(1 \mathrm{H}$, brs $), 6.19(1 \mathrm{H}$, brs $), 6.79(1 \mathrm{H}$, brs $), 7.06$ $(1 \mathrm{H}$, brs $) .{ }^{13} \mathrm{C}-\mathrm{NMR}\left(\mathrm{CDCl}_{3}\right) \delta: 25.6,28.1,28.4,35.9,39.1$, $40.3,40.5,55.8,60.2,60.3,61.8,61.9,69.9,70.0,70.1,79.3$, 156.2, 173.0, 173.8. HR-MS (ESI) $\mathrm{m} / \mathrm{z}$ : 497.2401 Calcd for $\mathrm{C}_{21} \mathrm{H}_{38} \mathrm{~N}_{4} \mathrm{O}_{6} \mathrm{~S}\left(\mathrm{M}+\mathrm{Na}^{+}\right)$: 497.2404).

\section{3-(Biotinylamino)propylamine (7a)}

Compound $7 \mathrm{a}$ was prepared differently from the reported procedure. $^{24)}$ Trifluoroacetic acid (TFA) $(739 \mu \mathrm{L}, 9.60 \mathrm{mmol})$ was added dropwise to a solution of $\mathbf{6 a}(384 \mathrm{mg}, 0.960 \mathrm{mmol})$ in $\mathrm{CH}_{2} \mathrm{Cl}_{2}(20.0 \mathrm{~mL})$ at $0^{\circ} \mathrm{C}$, and the mixture was stirred at room temperature for $3 \mathrm{~h}$. The solvent was then removed under reduced pressure to afford $7 \mathbf{a}$ ( $463 \mathrm{mg}$, TFA adduct, quant.) as an orange oil. This compound was used for the next reaction without further purification. 7a: ${ }^{1} \mathrm{H}-\mathrm{NMR}\left(\mathrm{CD}_{3} \mathrm{OD}\right)$ $\delta$ : $1.40(2 \mathrm{H}, \mathrm{tt}, J=7.4,7.4 \mathrm{~Hz}), 1.52-1.71(4 \mathrm{H}, \mathrm{m}), 1.80(2 \mathrm{H}, \mathrm{tt}$, $J=6.9,6.9 \mathrm{~Hz}), 2.19(2 \mathrm{H}, \mathrm{t}, J=7.4 \mathrm{~Hz}), 2.66(1 \mathrm{H}, \mathrm{d}, J=12.6 \mathrm{~Hz})$, $2.87-2.90(3 \mathrm{H}, \mathrm{m}), 3.16(1 \mathrm{H}, \mathrm{dt}, J=4.9,9.3 \mathrm{~Hz}), 3.23(2 \mathrm{H}$, $\mathrm{dt}, J=2.0,6.8 \mathrm{~Hz}), 4.26(1 \mathrm{H}, \mathrm{dd}, J=4.5,7.5 \mathrm{~Hz}), 4.46(1 \mathrm{H}$, $\mathrm{dd}, J=5.0,7.5 \mathrm{~Hz}$ ). HR-MS (ESI) $m / z$ : 323.1512 Calcd for $\mathrm{C}_{13} \mathrm{H}_{24} \mathrm{~N}_{4} \mathrm{O}_{2} \mathrm{~S}\left(\mathrm{M}+\mathrm{Na}^{+}\right)$: 323.1512).

\section{2-(2-(2-(Biotinylamino)ethoxy)ethoxy)ethylamine (7b)}

Compound $\mathbf{7 b}$ was prepared differently from the reported procedure. $^{23)}$ TFA $(200 \mu \mathrm{L}, 2.60 \mathrm{mmol})$ was added dropwise to a solution of the compound $\mathbf{6 b}(121 \mathrm{mg}, 0.260 \mathrm{mmol})$ in $\mathrm{CH}_{2} \mathrm{Cl}_{2}(2.00 \mathrm{~mL})$ at $0^{\circ} \mathrm{C}$, and the mixture was stirred at room temperature for $6 \mathrm{~h}$. The solvent was then removed under reduced pressure to afford $\mathbf{7 b}(129 \mathrm{mg}$, TFA adduct, quant.) as a yellow oil. 7b: ${ }^{1} \mathrm{H}-\mathrm{NMR}\left(\mathrm{CD}_{3} \mathrm{OD}\right) \delta$ : $1.35-1.37$ $(4 \mathrm{H}, \mathrm{m}), 1.47-1.67(4 \mathrm{H}, \mathrm{m}), 2.14(2 \mathrm{H}, \mathrm{t}, J=7.2 \mathrm{~Hz}), 2.63$ $(1 \mathrm{H}, \mathrm{d}, J=12.6 \mathrm{~Hz}), 2.84(1 \mathrm{H}, \mathrm{dd}, J=4.6,12.6 \mathrm{~Hz}), 3.04(2 \mathrm{H}$, brs), 3.12-3.15 (1H, m), $3.29(2 \mathrm{H}, \mathrm{t}, J=4.5 \mathrm{~Hz}), 3.47(2 \mathrm{H}, \mathrm{t}$, $J=5.0 \mathrm{~Hz}), 3.57(4 \mathrm{H}, \mathrm{brs}), 3.62(2 \mathrm{H}, \mathrm{t}, J=4.5 \mathrm{~Hz}), 4.24(1 \mathrm{H}$, brs), 4.43 (1H, brs). HR-MS (ESI) $m / z$ : 397.1872 Calcd for $\mathrm{C}_{16} \mathrm{H}_{30} \mathrm{~N}_{4} \mathrm{O}_{4} \mathrm{~S}\left(\mathrm{M}+\mathrm{Na}^{+}\right)$: 397.1880).

$\mathrm{N}$-(3-(Biotinylamino)propyl)-2,3-dichloromaleimide (5a)

A solution of 2,3-dichloromaleic anhydride $(22.0 \mathrm{mg}$, $0.130 \mathrm{mmol})$ and $7 \mathbf{a}(39.5 \mathrm{mg}, 0.130 \mathrm{mmol})$ in acetic acid $(1.00 \mathrm{~mL})$ was stirred at room temperature for $15 \mathrm{~min}$ under an $\mathrm{Ar}$ atmosphere. The mixture was then stirred at $120^{\circ} \mathrm{C}$ for $3 \mathrm{~h}$ and the solvent was removed under reduced pressure. The residue was purified by flash silica-gel chromatography $\left(\mathrm{CHCl}_{3}-\mathrm{MeOH}=20: 1\right.$ to $\left.15: 1\right)$ to afford 5a $(14.3 \mathrm{mg}$, $0.0318 \mathrm{mmol}, 24 \%)$ as a white solid. 5a: ${ }^{1} \mathrm{H}-\mathrm{NMR}\left(\mathrm{CD}_{3} \mathrm{OD}\right)$ $\delta$ : $1.35(2 \mathrm{H}, \mathrm{tt}, J=7.7,7.7 \mathrm{~Hz}), 1.49-1.65(4 \mathrm{H}, \mathrm{m}), 1.72(2 \mathrm{H}, \mathrm{tt}$, $J=7.0,7.0 \mathrm{~Hz}), 2.10(2 \mathrm{H}, J=7.0 \mathrm{~Hz}), 2.60(1 \mathrm{H}, \mathrm{d}, J=12.6 \mathrm{~Hz})$, 
$2.83(1 \mathrm{H}, \mathrm{dd}, J=5.2,12.6 \mathrm{~Hz}), 3.08(2 \mathrm{H}, \mathrm{t}, J=6.9 \mathrm{~Hz}), 3.12(1 \mathrm{H}$, $\mathrm{dt}, J=5.8,8.5 \mathrm{~Hz}), 3.51(2 \mathrm{H}, \mathrm{t}, J=7.2 \mathrm{~Hz}), 4.22(1 \mathrm{H}, \mathrm{dd}, J=4.3$, $7.8 \mathrm{~Hz}), 4,39(1 \mathrm{H}, \mathrm{dd}, J=4.8,7.8 \mathrm{~Hz}) .{ }^{13} \mathrm{C}-\mathrm{NMR}\left(\mathrm{CD}_{3} \mathrm{OD}\right) \delta$ : 26.8, 29.1, 29.5, 29.7, 36.8, 37.7, 37.9, 41.1, 57.0, 61.6, 63.3, 134.2, 164.5, 166.1, 176.2. HR-MS (ESI) $m / z: 471.0630$ Calcd for $\mathrm{C}_{17} \mathrm{H}_{22} \mathrm{Cl}_{2} \mathrm{~N}_{4} \mathrm{O}_{4} \mathrm{~S}\left(\mathrm{M}+\mathrm{Na}^{+}\right)$: 471.0631).

$\mathrm{N}$-(2-(2-(2-(Biotinylamino)ethoxy)ethoxy)ethyl)-2,3dichloromaleimide (5b)

A solution of 2,3-dichloromaleic anhydride $(8.90 \mathrm{mg}$, $0.0534 \mathrm{mmol})$ and $7 \mathbf{b}(20.0 \mathrm{mg}, 0.0534 \mathrm{mmol})$ in acetic acid $(0.200 \mathrm{~mL})$ was stirred at room temperature for $15 \mathrm{~min}$ under an $\mathrm{Ar}$ atmosphere. The mixture was then stirred at $120^{\circ} \mathrm{C}$ for $4 \mathrm{~h}$ and the solvent was removed by air-flow. The residue was purified by flash silica-gel chromatography $\left(\mathrm{CHCl}_{3}-\right.$ $\mathrm{MeOH}=20: 1$ to $15: 1)$ to afford $5 \mathbf{b}(15.8 \mathrm{mg}, 0.0302 \mathrm{mmol}$, $57 \%)$ as a white solid. 5b: ${ }^{1} \mathrm{H}-\mathrm{NMR}\left(\mathrm{CDCl}_{3}\right) \delta: 1.39(2 \mathrm{H}, \mathrm{tt}$, $J=7.6,7.6 \mathrm{~Hz}), 1.58-1.71(4 \mathrm{H}, \mathrm{m}), 2.22(2 \mathrm{H}, \mathrm{t}, J=7.4 \mathrm{~Hz}), 2.70$ $(1 \mathrm{H}, \mathrm{d}, J=13.2 \mathrm{~Hz}), 2.85(1 \mathrm{H}, \mathrm{dd}, J=4.9,12.9 \mathrm{~Hz}), 3.10(1 \mathrm{H}, \mathrm{dt}$, $J=4.5,7.3 \mathrm{~Hz}), 3.36(2 \mathrm{H}, \mathrm{t}, J=4.6 \mathrm{~Hz}), 3.46(2 \mathrm{H}, \mathrm{t}, J=5.2 \mathrm{~Hz})$, $3.49-3.50(2 \mathrm{H}, \mathrm{m}), 3.53-3.55(2 \mathrm{H}, \mathrm{m}) 3.61(2 \mathrm{H}, \mathrm{t}, J=5.4 \mathrm{~Hz})$, $3.75(2 \mathrm{H}, \mathrm{t}, J=5.4 \mathrm{~Hz}), 4.28(1 \mathrm{H}, \mathrm{dd}, J=4.6,8.0 \mathrm{~Hz}), 4.47(1 \mathrm{H}$, dd, $J=4.9,7.7 \mathrm{~Hz}), 6.68\left(2 \mathrm{H}\right.$, brs). ${ }^{13} \mathrm{C}-\mathrm{NMR}\left(\mathrm{CDCl}_{3}\right) \delta: 25.7$, $28.1,28.3,35.8,38.7,39.3,40.5,55.7,60.7,62.2,67.6,69.9$, $70.1,133.5,163.2,164.2,173.9$. HR-MS (ESI) $\mathrm{m} / z: 545.1005$ Calcd for $\mathrm{C}_{20} \mathrm{H}_{28} \mathrm{Cl}_{2} \mathrm{~N}_{4} \mathrm{O}_{6} \mathrm{~S}\left(\mathrm{M}+\mathrm{Na}^{+}\right)$: 545.0999).

Spectrometric Analysis Methanol for spectrochemical analysis was purchased from Wako Pure Chemical Industries, Ltd. and 1,4-dioxane for spectrochemical analysis was purchased from Kanto Chemical Co., Inc. The absorption spectra were recorded on a Shimadzu UV-2400PC spectrometer equipped with a $50 \mathrm{~W}$ halogen lamp, and a deuterium lamp (slit width: $0.2 \mathrm{~nm}$ ). The fluorescence measurements were performed on a JASCO FP-6500 equipped with a $150 \mathrm{~W}$ xenon lamp (slit width: $3 \mathrm{~nm}$ ). A $1.00 \mathrm{~cm}$ quartz cell was used for the measurements.

\section{Biological Assay}

Material Preparation

Streptavidin was purchased from Wako Pure Chemical Industries, Ltd. (streptavidin from Streptomyces avidinii, $>90 \%$, 10-20 units/mg). BSA was purchased from Sigma-Aldrich Co., LLC (Bovine Serum Albumin, 96-99\%), CAII was also purchased from Sigma-Aldrich Co., LLC (Carbonic Anhydrase Isozyme II from bovine erythrocytes, $\geq 3000 \mathrm{~W}-\mathrm{A}$ units $/ \mathrm{mg}$ protein). The proteins were used without further purification. Streptavidin, BSA and CAII were dissolved in MilliQ water, and the concentrations were determined by measuring the absorbance at $280 \mathrm{~nm}$. The HEK-293 cell lysate was prepared as follows. HEK-293 cells were cultured in Dulbecco's modified Eagle's medium (DMEM) containing 10\% fetal bovine serum (FBS) and penicillin/streptomycin at $37^{\circ} \mathrm{C}$ in a humidified atmosphere of $5 \% \mathrm{CO}_{2}$. The cell pellet was lysed with solubilization buffer (20 mM $N$-(2-hydroxyethyl)piperazine- $N N^{\prime}$-(2ethanesulfonic acid) sodium salt (Hepes-Na) (pH 7.0), $1.0 \mathrm{~mm}$ ethylenediaminetetraacetic acid (EDTA), $0.5 \%$ Triton X-100, and complete mini (Roche, Switzerland)) for $15 \mathrm{~min}$ on ice and centrifuged at $15000 \times \mathbf{g}$ for $10 \mathrm{~min}$ at $4^{\circ} \mathrm{C}$. The resulting supernatant was collected and used as HEK-293 cell lysate.

General Labeling Procedure

Streptavidin was incubated with test compound in phosphate buffer $(100 \mu \mathrm{L}, \mathrm{pH} 7.0)$ for $30 \mathrm{~min}$ at $0^{\circ} \mathrm{C}$. In the competition analysis, streptavidin was pre-incubated with biotin for
$30 \mathrm{~min}$ at $0^{\circ} \mathrm{C}$ before addition of test compound, and the excess probes were removed by Amicon ${ }^{\circledR}$ Ultra- $0.5 \mathrm{~mL}$ (Merck Millipore Ltd., Germany), after the labeling reaction. The resulting sample was mixed with 5x SDS-PAGE loading buffer, heated for $20 \mathrm{~min}$ at $120^{\circ} \mathrm{C}$, and subjected to SDS-PAGE. The gel was visualized with an in-gel fluorescence imager (ATTO Ez-Capture II) (diaphragm: 3.0, exposure time: $5 \mathrm{~s}$ ) equipped with WSE-5500 VariRays $\left(\lambda_{\text {ex }}: 440-500 \mathrm{~nm}\right.$, peak: $\left.470 \mathrm{~nm}\right)$ and stained with Commassie Brilliant Blue (see Pico $^{\mathrm{TM}}$ CBB Stain Kit).

Acknowledgments The work described in this paper was partially supported by Grants-in-Aid for Scientific Research (KAKENHI, Grant-in-Aid for Young Scientists (B), No. 26810091 and No. 16K17930 to T.Y.) from The Ministry of Education, Culture, Sports, Science and Technology (MEXT) of Japan, and the Japan Society for the Promotion of Science (JSPS), and Platform for Drug Discovery, Informatics, and Structural Life Science.

Conflict of Interest The authors declare no conflict of interest.

\section{References}

1) Takaoka Y., Ojida A., Hamachi I., Angew. Chem. Int. Ed., 52, 4088-4106 (2013).

2) Park J., Koh M., Park S. B., Mol. Biosyst., 9, 544-550 (2013).

3) Park J., Koh M., Koo J. Y., Lee S., Park S. B., ACS Chem. Biol., 11, 44-52 (2016).

4) Yamaguchi T., Asanuma M., Nakanishi S., Saito Y., Okazaki M., Dodo K., Sodeoka M., Chem. Sci., 5, 1021-1029 (2014).

5) Shen B. Q., Xu K., Liu L., Raab H., Bhakta S., Kenrick M., Parsons-Reponte K. L., Tien J., Yu S. F., Mai E., Li D., Tibbitts J., Baudys J., Saad O. M., Scales S. J., McDonald P. J., Hass P. E., Eigenbrot C., Nguyen T., Solis W. A., Fuji R. N., Flagella K. M., Patel D., Spencer S. D., Khawli L. A., Ebens A., Wong W. L., Vandlen R., Kaur S., Sliwkowski M. X., Scheller R. H., Polakis P., Junutula J. R., Nat. Biotechnol., 30, 184-189 (2012).

6) Gunnoo S. B., Madder A., ChemBioChem, 17, 529-533 (2016).

7) Baslé E., Joubert N., Pucheault M., Chem. Biol., 17, 213-227 (2010). 8) Holmes K. L., Lantz L. M., Methods Cell Biol., 63, 185-204 (2001).

9) Kim Y., Ho S. O., Gassman N. R., Korlann Y., Landorf E. V., Collart F. R., Weiss S., Bioconjug. Chem., 19, 786-791 (2008).

10) Smith M. E. B., Schumacher F. F., Ryan C. P., Tedaldi L. M., Papaioannou D., Waksman G., Caddick S., Baker J. R., J. Am. Chem. Soc., 132, 1960-1965 (2010).

11) Schumacher F. F., Nobles M., Ryan C. P., Smith M. E. B., Tinker A., Caddick S., Baker J. R., Bioconjug. Chem., 22, 132-136 (2011).

12) Moody P., Smith M. E. B., Ryan C. P., Chudasama V., Baker J. R., Molloy J., Caddick S., ChemBioChem, 13, 39-41 (2012).

13) Robin M. P., Wilson P., Mabire A. B., Kiviaho J. K., Raymond J. E., Haddleton D. M., O’Reilly R. K., J. Am. Chem. Soc., 135, 2875-2878 (2013).

14) Nathani R. I., Chudasama V., Ryan C. P., Moody P. R., Morgan R. E., Fitzmaurice R. J., Smith M. E. B., Baker J. R., Caddick S., Org. Biomol. Chem., 11, 2408-2411 (2013).

15) Youziel J., Akhbar A. R., Aziz Q., Smith M. E. B., Caddick S., Tinker A., Baker J. R., Org. Biomol. Chem., 12, 557-560 (2014).

16) Marculescu C., Kossen H., Morgan R. E., Mayer P., Fletcher S. A., Tolner B., Chester K. A., Jones L. H., Baker J. R., Chem. Commun., 50, 7139-7142 (2014)

17) Smith M. E. B., Caspersen M. B., Robinson E., Morais M., Maruani A., Nunes J. P. M., Nicholls K., Saxton M. J., Caddick S., Baker J. R., Chudasama V., Org. Biomol. Chem., 13, 7946-7949 (2015). 
18) Ramesh S., Cherkupally P., Govender T., Kruger H. G., Albericio F., Torre B. G., Chem. Commun., 52, 2334-2337 (2016).

19) Mabire A. B., Robin M. P., Quan W. D., Willcock H., Stavros V. G., O'Reilly R. K., Chem. Commun., 51, 9733-9736 (2015).

20) Mahle F., da Rosa Guimarães T., Vergilina Meira A., Corrêa R., Bella Cruz R. C., Bella Cruz A., Nunes R. J., Cechinel-Filho V., de Campos-Buzzi F., Eur. J. Med. Chem., 45, 4761-4768 (2010).

21) Ji W., Ji Y., Jin Q., Tong Q., Tang X., Analyst, 140, 4379-4383
(2015)

22) Weber P. C., Ohlendorf D. H., Wendoloski J. J., Salemme F. R., Science, 243, 85-88 (1989).

23) Gnaccarini C., Ben-Tahar W., Lubell W. D., Pelletier J. N., Keillor J. W., Bioorg. Med. Chem., 17, 6354-6359 (2009).

24) Spjut S., Pudelko M., Hartmann M., Elofsson M., Eur. J. Org. Chem., 2009, 349-357 (2009). 